\title{
Effects of Intra-Interspesific Competitions on Yield and Yield Component of Maize under Different Intercropping Patterns
}

\author{
M.A. Abou-Keriasha, R.A. Gadallah, and N.M.H. El-Wakil \\ Crop Intensification Research Department, Field Crop \\ Research Institute, Agricultural Research Center, Giza, Egypt.
}

\begin{abstract}
TWO EXPERIMENTS were conducted during the growing I summer seasons 2008-2009 at Shandaweel Agric. Res. St., (Upper Egypt) to study the effect of intercropping maize with sorghum, soybean and cowpea on yield and yield components. There were three intercropping crops: $A_{1}$ (maize + sorghum), $A_{2}$ (maize+ soybean) and $A_{3}$ (maize + cowpea) in three intercropping patterns $P_{1}$, $\mathrm{P}_{2}$ and $\mathrm{P}_{3}(2: 2,2: 4$ and 4:4), respectively. The experiments were established as split plots intercropped in randomized complete block design (RCBD) with three replications. The results show significantly higher values of yield and yield components were recorded by the maize + soybean intercrop followed by the maize + cowpea intercrop in both seasons. The yield and yield components of intercropped crops (sorghum, soybean and cowpea) were decreased as compared with solid. The reduction in yield and yield components of this crops due to the shading of maize plants, that results in decrease interception of solar radiation from top of maize crop to top of intercropped crops (soybean and cowpea). The reductions in light intensity of the treatments maize + soybean and maize + cowpea intercrops were 39 and $38 \%$ in the combined of the two seasons as compared with solid planting. The highest of yield and yield components were recorded by 2:4 pattern $\left(\mathrm{P}_{2}\right)$ compared with the other patterns $(2: 2$ and $4: 4)$ due to light interception that was greater in $2: 4$. The reduction in yield were 51,44 and $52 \%$ for maize 61,43 and $59 \%$ for sorghum, 60,33 and $60 \%$ for soybean and 53.33 and 58\% for cowpea in 2:2, 2:4 and 4:4 patterns compared with solid in both seasons, respectively. The total land equivalent ratio (LER) value was (1.22) when intercropped with soybean or cowpea. A similar trend to that of the LER was observed for relative crowding coefficient (Rcc), aggressivity (Agg) and competition ratio (CR). The highest values of monetary advantage index (MAI) (1044.46) were observed when intercropping with soybean at $4: 4$ pattern, while the lowest value was observed in maize + sorghum intercrop at 2:4 pattern. The data of aggressivity showed that maize was the dominant (Ag positive) and the intercropped crops were dominated (Ag negative).
\end{abstract}

Keyword: Intercropping, Competition, Patterns, Cereal, Legume, Sequence. 
Competition is one of the factors that can have a significant impact on the yield of intercropped crop compared with pure stand (Caballero et al., 1995). Competition among plants involves a struggle for limited resources such as sunlight, water and nutrients supplied in the soil. Types of competition are intraspecific which are between plants of the same species (maize -maize) and interspecific which are between plants of different species (maize - soybean). Intraspecific competition is the most aggressive because plants of the same species have the same needs and same resources (Alexander et al., 1970). Higher yields have been reported when competition between the two species of intercrop (maize + soybean) was lower than competition with the same species (Vandermeer, 1989).

Agyar et al., (2006) and Songa et al. (2007) observed intra and inter specific competition in many combinations of several crops (maize, sorghum, millet, cassava and bean). So the maize grain yield produced in the combination maize + bean was higher than in the combination maize+sorghum, while the combination maize +millet showed the lowest grain yield. The highest values of LER were calculated for maize + bean which were always considerably $>1.5$ followed by maize + sorghum in $50 \%$ of the studied cases. Dhima et al. (2007) showed that LER, K, Ag and K values were greater for barley and oat than for wheat and triticale, whereas the corresponding values for vetch were lower with barley and oat than with wheat and triticale.

Relative plant heights of different crops grown in association in an intercrop system are important. Profiles of light intensity and leaf area indices in crop canopies indicate that the taller crop has an advantage over its shorter crop companions (Tranbath, 1974). Short grain sorghum offer less competition to intercropped crops than taller ones. Elmure \& Jackoba (1984), Abou-Keriasha et al. (1993 and 1996) found that seed yield of soybean or sunflower grown with taller sorghum was lower than that produced with the shorter ones.

Light is one of the important growth factors affecting crop yields. Low availability of light for a component crop in the mixture reduced the photosynthesis rate and crop growth rate and eventually limited lighting leads to drastic reduction in grain and straw yields of component crops. Donald (1961) noted that the decrease in interception of solar radiation from the top of maize crop to the top of legume intercrop was due to shading by maize canopy. This reduction of reception of light energy by legume reduced the yield of intercrops in maize. Chandel et al. (1993) reported that the light transmission in soybean + maize intercrop was decreased by 6.5 to 2.3 and 0.10 to 0.5 percent in a single row $(60 \mathrm{~cm})$ and in paired rows (30190) cm respectively. Behairy (1994) found that light utilization in 4 rows soybean: 2 rows maize ratio more than in 2:2 row ratio.

Abo-Hegazy (2010) and Metwally (2010) showed that light intensity of middle and bottom plants at 40 and 70 days age were considerably higher as compared with solid maize. Solid planting of soybean was associated with higher intercepted light intensity on soybean plants as compared with soybean intercropping patterns.

Egypt. J. Agron. 34, No. 2 (2012) 
In general, cereal crop yields increase when intercropped with legumes crops, while legume yields are decline in legume crop intercropping systems (Fortin et al. 1994 and Lesoing \& Francis, 1999). Abou-Keriasha (1993) and Metwally et al. (2009) found that two ridges maize: four ridges soybean (2: 4) pattern produced more kernel number per row, kernels weight of ear, 100-kernels weight, shelling percentage and grain yield/ fed as compared with 2: 2 pattern. Sanari Moriri et al. (2010) showed that the 1 row maize: 1 row cowpea system was superior in maize dry matter while the 2 rows maize: 4 rows cowpea has the lowest cowpea dry matter and tallest cowpea plant height. Echezona (2007) reported that the plant height of maize was influenced by cropping systems. The plant height was higher under 1: 1 pattern than the other patterns (1:2 and 1:3). The maize grain yield in 1:2 pattern was associated with higher values and in 1: 3 pattern was the lowest values. While seed yield of soybean was higher in 1: 3 pattern compared the other patterns $(1: 1$ and 1:2).

The objectives of this study were to estimate the effect of competition among the different species used in intercropping systems, i.e. Maize, sorghum, soybean and cowpea in three intercropping patterns (2:2, 2:4 and 4:4) and find the better system which lend to better productivity, less competition and best economic parameters.

\section{Materials and Methods}

Two experiments were conducted during the growing summer seasons (2008 and 2009) at Shandaweel Agriculture Research Station (Upper Egypt). This study aimed to evaluate the effects of intercropping maize (TWC 310) as the main crop with hybrid sorghum (cv Shandaweel-1), soybean (cv Giza 111) and cowpea (cv Cream) on yield and yield components. These three intercropping crops were denoted $A_{1}$ (maize + sorghum), $A_{2}$ (maize + soybean) and $A_{3}$ (maize + cowpea). These systems were performed in three intercropping patterns $\mathrm{P}_{1}, \mathrm{P}_{2}$ and $\mathrm{P}_{3}(2: 2,2: 4$ and 4:4), respectively. The experiments were carried out as split plots intercropped in randomized complete block design (RCED) with three replications. The three intercropping crops $\left(A_{1}-A_{3}\right)$ were randomly distributed to occupy the main plots while the three intercropping patterns $\left(\mathrm{P}_{1}-\mathrm{P}_{3}\right)$ were randomly laid out on the sub plots. The sub plot area $(8.4 \times 4 \mathrm{~m})$ consisted of 12 ridges. The proposed stands for studied crops were respected for comparisons. Maize and sorghum were grown on one side of ridges in one plant/ hill at 30 and $20 \mathrm{~cm}$ apart, respectively (solid or intercrop). Soybean was planted on the two sides of ridges in two plants/ hill at $10 \mathrm{~cm}$ between hills and cowpea was planted on one side of ridges in two plants / hill at $10 \mathrm{~cm}$ between. The crops (cereal and legumes) were sown in the last week of May during the two seasons. During seedbed preparation $50 \mathrm{~kg} \mathrm{P}_{2} \mathrm{O}_{5}$ fed $^{-1}$ in the form of calcium superphosphate $\left(\begin{array}{ll}15.5 \% & \mathrm{P}_{2} \mathrm{O}_{5}\end{array}\right)$ was added and Nitrogen fertilizer for maize or sorghum was added at the rate of 120 and $70 \mathrm{~kg} \mathrm{fed}^{-1}$, respectively in the form of ammonium sulfate $(20.5 \% \mathrm{~N})$ in the three equal doses. The legume crops were taken $20 \mathrm{~kg}$ fed. $^{-1}$. Potassium fertilizer at the rate of $50 \mathrm{~kg} \mathrm{fed}^{-1}$ in form of potassium sulfate $48 \% \mathrm{~K}_{2} \mathrm{O}$ which was added with the first dose of nitrogen. 
Harvesting took place in the last week of September. Maize and sorghum were harvested at complete maturity while legumes (soybean and cowpea) were harvested when the first pod of the plants fully material. Kernels and seeds were weighted and adjusted to constant moisture of $14 \%$ and $12 \%$ for cereal and legume crops, respectively. At harvest, samples of ten plants each were taken from each subplot and data were recorded for growth traits and yield components.

Maize: plant height $(\mathrm{cm})$, ear height $(\mathrm{cm})$, ear length $(\mathrm{cm})$, ear diameter $(\mathrm{cm})$, number of grains/ row, grain weight of ear $(\mathrm{g})$, weight of 100 grain $(\mathrm{g})$, shelling percentage, percentage light intensive and grain yield of maize (ardab/fed $\operatorname{ardab}=140 \mathrm{~kg}$ ) were measured.

Sorghum: plant height $(\mathrm{cm})$, weight of head $(\mathrm{g})$, weight of 100 grain $(\mathrm{g})$, weight of grain/ head (g), shelling percentage, percentage light intensive and grain yield of sorghum were determined [ $\left(\mathrm{ardab} / \mathrm{fed}^{-1}\right.$ ardab=140 kg), feddan = $4200 \mathrm{~m}^{2}$ ].

Soybean: plant height $(\mathrm{cm})$, number of seed/ pod, number of pod/plant, seed yield feddan (ton), straw yield (ton) and percentage light intensive.

Cowpea: plant height $(\mathrm{cm})$, number of branches, number of seed/ plant, number of seed/ pod, weight of 100 seed $(\mathrm{g})$, percentage light intensive, straw yield (ton) and seed yield (ton $=1000 \mathrm{~kg}$ ).

Light intensity measurements were recorded between plants, maize, sorghum, soybean and cowpea at 70 days from sowing dates. Light intensity inside of each canopy was measured by Lux-meter apparatus at $12 \mathrm{AM}$ in the middle of the plant. (Lux) values of light intensity were transformed as a percentage from light intensity measured above maize plants, i.e. outside the plant population (Szeicz et al., 1964).

Competitions indices and monetary advantage

The benefit of planting patterns and the effect of competition between the four species used in this experiment were calculated using different competition indices.

Competitive relationships

Land equivalent ratio (LER)

Land equivalent ratio LER was determined according to (Willey \& Osiru (1972) with the following formula:

$$
L E R=\frac{y a b}{y a a}+\frac{y b a}{y b b}
$$

where: Yaa is pure stand yield of crop a, Ybb is pure stand yield of crop b, Yab is yield of $a$ (when combined with $b$ ) and Yba yield of $b$ (when combined with $a$ ).

Egypt. J. Agron. 34, No. 2 (2012) 
Relative crowding coefficient ( Rcc)

According to Dewit (1960) K for crop a, ( K ) for crop b and ( Rcc ) for the two crops were calculated as follows :-

$$
K a b=\frac{y a b \times z b a}{(y a a-y a b) \times z a b}, K b a=\frac{y b a \times z a b}{(y b b-y b a) \times z b a}
$$

where $: z a b=$ sown proportion of crop $a($ in a intercropping with $b)$. $\mathrm{zba}=$ sown proportion of crop $\mathrm{b}$ ( in $\mathrm{b}$ intercropping with $\mathrm{a}$ ).

Aggressivity ( Agg )

This was proposed by Mc-Gilichrist (1960) and was determined according to the following formula:

$$
A g a=\frac{y a b}{y a a \times z a b}-\frac{y b a}{y b b \times z b a}, \quad A g b=\frac{y b a}{y b b \times z b a}-\frac{y a b}{y a a \times z a b}
$$

Competitive ratio $(C R)$

It was calculated by following the formula as advocated by Willey \& Rao (1980)

$$
\mathrm{CR}=\mathrm{CRa} \text { or } \mathrm{CRb} \mathrm{CRa}=\left\{\left(\frac{L E R a}{L E R b}\right) \times\left(\frac{Z b a}{Z a b}\right)\right\} \text {, }
$$

Monetary advantage index (MAI)

It suggests that the economic assessment should be in terms of the value of land saved; this could probably be most assessed on the basis of the rentable value of this land. MAI was calculated according to the formula, suggested by Willey (1979).

$$
M A I=\frac{\text { Value of combined intercrops } \times \text { LER }-1}{L E R}
$$

In Egyptian pound maize price was 195.5 L.E /ardab, sorghum 203 L.E / ardab, soybean 2184 L.E/ton and cowpea seed 1900 L.E /ton of the two seasons. All data were statistically analyzed according to Snedecor \& Cochran (1988) using MSTATC software Computer $\mathrm{V}_{4}$ (1980). LSD test at 5\% level was used to compare between treatments.

\section{Results and Discussion}

Effect of intercropped crops (cereal and legume crops) on growth, yield and yield components of maize

Data in Table 1 shows significant differences in all studied characters except shelling percentage in the combined of the two seasons. The results clearly show that intercropping with other crops resulted in taller maize plants compared with 
solid planting. The highest values were observed when intercropping maize with cowpea $\left(A_{3}\right)$ followed by soybean $\left(A_{2}\right)$. This was mainly due to complementary effect between the main crops (maize) and intercropped crops, (cowpea and soybean) that were short statured crop and grow about 1/3 of the plant height of main crop, (maize) and presented lesser resistance for maize growth for scarce resource like soil moisture, nutrients and light which is higher than in interspecific (Alexander et al., 1970 and Vandermeer, 1989).

TABLE 1. Effect of intercropping crops (sorghum, soybean and cowpea) on growth yield and yield components of maize (main crop) of the two seasons and combined data.

\begin{tabular}{|c|c|c|c|c|c|c|c|c|c|c|}
\hline $\begin{array}{l}\text { Intercropping } \\
\text { crops }\end{array}$ & $\begin{array}{c}\text { Plant } \\
\text { height } \\
(\mathrm{cm})\end{array}$ & $\begin{array}{c}\begin{array}{c}\text { Ear } \\
\text { height } \\
(\mathbf{c m})\end{array} \\
\end{array}$ & $\begin{array}{c}\text { Ear } \\
\text { length } \\
(\mathrm{cm})\end{array}$ & $\begin{array}{c}\text { Ear } \\
\text { diameter } \\
(\mathbf{c m})\end{array}$ & $\begin{array}{c}\text { No. of } \\
\text { grain/ } \\
\text { row }\end{array}$ & $\begin{array}{l}\text { Wt.of } \\
100 \\
\text { grain } \\
(\mathrm{g})\end{array}$ & $\begin{array}{c}\text { Wt.of } \\
\text { grain/ } \\
\text { ear } \\
\text { (g) }\end{array}$ & $\begin{array}{c}\text { Shelling } \\
\%\end{array}$ & $\begin{array}{c}\text { Grain } \\
\text { yield/ } \\
\text { ardab }\end{array}$ & $\begin{array}{c}\text { Percentage } \\
\text { of light } \\
\text { intensity }\end{array}$ \\
\hline \multicolumn{11}{|c|}{ Season 2008} \\
\hline $\mathrm{A}_{1}$ & 282.3 & 165.78 & 22.89 & 3.76 & 51.39 & 38.55 & 234.06 & 85.28 & 12.96 & 24.33 \\
\hline $\mathrm{A}_{2}$ & 287.9 & 162.10 & 22.96 & 3.79 & 50.31 & 38.56 & 246.11 & 85.36 & 13.99 & 34.45 \\
\hline $\mathrm{A}_{3}$ & 292.0 & 165.89 & 23.85 & 3.75 & 52.70 & 39.00 & 242.11 & 85.16 & 14.34 & 34.11 \\
\hline LSD 5\% & NS & NS & NS & 0.21 & 0.84 & NS & 2.72 & NS & NS & 1.71 \\
\hline Solid & 275.0 & 154.7 & 21.1 & 3.30 & 46.2 & 35.6 & 226.6 & 84.30 & \begin{tabular}{|l|}
20.77 \\
\end{tabular} & 22.33 \\
\hline \multicolumn{11}{|c|}{ Season 2009} \\
\hline $\mathrm{A}_{1}$ & 281.80 & 158.45 & 22.00 & 3.55 & 50.34 & 35.33 & 224.22 & 84.33 & 12.55 & 24.11 \\
\hline $\mathrm{A}_{2}$ & 285.70 & 162.67 & 22.06 & 3.93 & 52.78 & 37.89 & 227.00 & 85.67 & 14.37 & 33.74 \\
\hline $\mathrm{A}_{3}$ & 300.70 & 175.22 & 21.67 & 3.88 & 51.55 & 35.78 & 225.89 & 85.00 & 14.15 & 34.89 \\
\hline LSD $5 \%$ & 13.23 & 4.08 & 0.53 & 0.12 & 0.31 & 1.27 & 1.87 & NS & NS & 0.95 \\
\hline Solid & 279.90 & 157.00 & 21.80 & 3.23 & 46.00 & 31.00 & 221.00 & 85.00 & 20.00 & 23.66 \\
\hline \multicolumn{11}{|c|}{ Combined of the two seasons } \\
\hline $\mathrm{A}_{1}$ & 282.0 & 162.11 & 22.45 & 3.63 & 50.94 & 36.95 & 229.14 & 84.81 & 12.75 & 24.22 \\
\hline $\mathrm{A}_{2}$ & 286.8 & 162.33 & 22.51 & 3.86 & 51.54 & 38.22 & 236.56 & 85.02 & 14.17 & 34.08 \\
\hline $\mathrm{A}_{3}$ & 296.3 & 170.67 & 22.76 & 3.81 & 52.13 & 37.39 & 234.00 & 85.08 & 14.24 & 34.50 \\
\hline LSD 5\% & 10.79 & 3.23 & 0.85 & 0.11 & 0.37 & 0.77 & 1.37 & NS & 0.45 & 0.81 \\
\hline Solid & 277.45 & 155.85 & 21.45 & 3.27 & 46.10 & 33.3 & 223.8 & 84.65 & 20.39 & 22.99 \\
\hline
\end{tabular}

Hectare $=10.000 \mathrm{~m}^{2}$, feddan $=4200 \mathrm{~m}^{2}$, maize $\operatorname{ardab}=140 \mathrm{~kg}$

Significantly higher values of some yield components (ear diameter, weight of grain of ear and weight of 100 grain) were recorded by maize + soybean and the other yield components (ear length, number of grain/row) were recorded by maize + cowpea intercrops (combined of the two seasons) while, the lowest values were observed in maize + sorghum intercrop. The increase of yield components of maize in maize + soybean and maize + cowpea intercrops systems was due to plants accepting higher values for intercepted light intensity on maize plants compared with other treatments.

Egypt. J. Agron. 34, No. 2 (2012) 
Light intensity at middle of maize at 70 days age in maize + soybean intercrop considerably increased by $48 \%$ and by $50 \%$ in maize + cowpea intercrop compared with solid in combined of the two seasons, respectively. Also, light intensity on maize + sorghum intercrop was increased by $5 \%$ as compared with solid in the combined of the two seasons. These results are in agreement with this by Agyare et al. (2006) and Songa et al. (2007).

The solid planting has the lowest values of yield components, but produced the highest grain yield / fed and it was due to population percent of maize in solid planting $(100 \%)$. Grain yield of maize + soybean and maize + cowpea intercrops was $69.5 \%$ and $69.8 \%$ of solid in the combined of the two seasons. Increasing grain yield was main crop in maize + legume systems due to less competition between the two species plants and the greater available light. While the grain yield in maize + sorghum intercrop was $62.5 \%$ of solid in the combined of the two seasons its due to shortness of sorghum plants which only grew to about $2 / 3$ of the plant height of maize and presented lesser resistance for maize growth therefore, it can be stated that the short varieties of sorghum had less competition. Similar results were reported by Donald (1961).

Effect of intercropping patterns on growth, yield and yield components of maize

Significant differences were observed in all characters expect plant height and shelling percentage in the combined of the two seasons (Table 2). The results indicated that intercropping patterns had effect pronounced on plant height and ear height the 2:2 pattern had the tallest plants compared with the other patterns. The increasing plant height in 2:2 pattern was due to that competition between plants on light utilization which was higher in 2:2 pattern compared with 2:4 pattern. The highest values of yield components of maize were recorded when 2:4 pattern $\left(\mathrm{P}_{2}\right)$ was applied as compared with the other patterns (2:2 and 4:4). The increase of yield components of maize in 2:4 patterns was due more light interception which was greater than in 2:2 and stimulate plant development may explain the greater yield in 2:4 patterns compared with the other pattern. Light intensity on maize plants at middle of plants at 70 days age in $2: 4$ pattern increased by $6.2 \%$ over $2: 2$ pattern and by $40 \%$ over solid planting in the combined of the two seasons. Similar results were observed by Metwally et al. (2009). The maize grain yield was significantly higher in $4: 4$ patterns $\left(17.96 \mathrm{ardab} \mathrm{fed}^{-1}\right)$ followed by $2: 2$ pattern (14.03 ardab fed $\left.\mathrm{ad}^{-1}\right)$ as compared with in 2:4 pattern $\left(11.19 \mathrm{ardab} \mathrm{fed}^{-1}\right)$ due to higher population of maize ( $50 \%$ of solid). The patterns $2: 4$ have the highest values of yield components but recorded the third in productivity due to less population of maize in this pattern (33.3\% of solid). These obtained are in agreement by Abou-Keriash (1993) and Metwally et al. (2009). 
TABLE 2. Effect of intercropping patterns on growth yield and yield components of maize (main crop) of the two seasons and combined data.

\begin{tabular}{|c|c|c|c|c|c|c|c|c|c|c|}
\hline Characters & $\begin{array}{c}\text { Plant } \\
\text { height } \\
(\mathbf{c m})\end{array}$ & $\begin{array}{c}\text { Ear } \\
\text { height } \\
(\mathbf{c m})\end{array}$ & $\begin{array}{l}\text { Ear } \\
\text { length } \\
(\mathbf{c m})\end{array}$ & $\begin{array}{c}\text { Ear } \\
\text { diameter } \\
(\mathrm{cm})\end{array}$ & $\begin{array}{l}\text { No. of } \\
\text { grain/ } \\
\text { row }\end{array}$ & $\begin{array}{c}\text { Wt.of } \\
100 \\
\text { grain } \\
\text { (g) }\end{array}$ & $\begin{array}{l}\text { Wt.of } \\
\text { grain/ } \\
\text { ear } \\
\text { (g) }\end{array}$ & $\begin{array}{c}\text { Shelling } \\
\%\end{array}$ & $\begin{array}{l}\text { Grain } \\
\text { yield/ } \\
\text { ardab }\end{array}$ & $\begin{array}{l}\text { Percentage } \\
\text { of light } \\
\text { intensity }\end{array}$ \\
\hline \multicolumn{11}{|c|}{ Season 2008} \\
\hline $\mathrm{P}_{1}$ & 290.2 & \begin{tabular}{|l|}
165.56 \\
\end{tabular} & 22.50 & 3.58 & 50.28 & 35.44 & 237.11 & 85.29 & 13.06 & 30.33 \\
\hline $\mathrm{P}_{2}$ & 282.0 & 168.00 & 22.55 & 3.91 & 52.57 & 40.44 & 241.89 & 85.86 & 11.34 & 32.00 \\
\hline $\mathrm{P}_{3}$ & 290.0 & \begin{tabular}{|l|}
160.22 \\
\end{tabular} & 24.64 & 3.75 & 51.72 & 40.22 & 243.28 & 84.66 & 18.61 & 30.56 \\
\hline LSD 5\% & NS & NS & 1.56 & 0.21 & 1.73 & 1.44 & 3.80 & NS & 0.83 & NS \\
\hline Solid & 275.0 & 154.70 & 21.10 & 3.30 & 46.20 & 35.60 & 226.60 & 84.30 & 20.77 & 22.33 \\
\hline \multicolumn{11}{|c|}{ Season 2009} \\
\hline $\mathrm{P}_{1}$ & 289.7 & 166.67 & 21.14 & 3.71 & 49.00 & 35.11 & 224.89 & 84.56 & 15.00 & 30.24 \\
\hline $\mathrm{P}_{2}$ & 290.6 & 166.89 & 22.44 & 3.98 & 52.00 & 37.22 & 225.78 & 85.00 & 11.04 & 32.33 \\
\hline $\mathrm{P}_{3}$ & 287.9 & 162.67 & 21.83 & 3.66 & 53.67 & 36.67 & 226.44 & 84.44 & 17.31 & 30.14 \\
\hline LSD 5\% & NS & 2.46 & 0.53 & 0.12 & 1.38 & 0.74 & NS & NS & 0.37 & NS \\
\hline Solid & 279.9 & 157.00 & 21.80 & 3.23 & 46.00 & 31.00 & 221.00 & 85.00 & 20.00 & 23.66 \\
\hline \multicolumn{11}{|c|}{ Combined of the two seasons } \\
\hline $\mathrm{P}_{1}$ & 290.0 & 166.11 & 21.97 & 3.65 & 46.64 & 35.28 & 231.0 & 84.92 & 14.03 & 30.29 \\
\hline $\mathrm{P}_{2}$ & 285.7 & 167.44 & 23.13 & 3.95 & 52.28 & 38.83 & 233.83 & 85.43 & 11.19 & 32.17 \\
\hline $\mathrm{P}_{3}$ & 288.5 & 161.44 & 22.60 & 3.71 & 52.69 & 38.44 & 234.88 & 84.55 & 17.96 & 30.35 \\
\hline LSD 5\% & NS & 4.26 & 0.85 & 0.11 & 0.05 & 0.77 & 1.91 & NS & 0.43 & 1.07 \\
\hline Solid & 277.45 & 155.85 & 21.45 & 3.27 & 46.10 & 33.3 & 223.8 & 84.65 & 20.39 & 22.99 \\
\hline
\end{tabular}

Hectare $=10.000 \mathrm{~m}^{2}$, feddan $=4200 \mathrm{~m}^{2}$, maize $\operatorname{ardab}=140 \mathrm{~kg}$

\section{The interaction effects}

There were significant interaction effect between companion crops and intercropping patterns except for plant height ear diameter, weight of grain ear shelling percentage and percentage of light intensity (Table 3). The plant height of maize reached the maximum values in maize + cowpea intercrop with 4:4 pattern with all intercropping crops, while the minimum values was recorded maize + sorghum intercrop with $2: 4$ pattern. The maximum values of most yield components were observed in maize + soybean and maize + cowpea with 2:4 pattern except weight of grain ear and grain yield, whereas the minimum values ears of length and diameter, number of grain/rows, weights of 100 grain and grain ear were observed in maize + sorghum intercrop with 2:2 pattern. The maximum values of grain yield (18.31 $\left.\mathrm{ardab} \mathrm{fed}^{-1}\right)$ were recorded by maize + cowpea intercrop with 4:4 patterns, while the minimum values (8.34) was observed maize + sorghum intercrop with 2:4 pattern. The increases in grain yield /fed when intercropped maize with legume crops (soybean or cowpea) in 4:4 pattern were due to high plants population of maize (50\% of solid) which was associated with higher values for light interception by maize plants. Similar results were those obtained by Agyare et al. (2006) and Songa et al. (2007).

Egypt. J. Agron. 34, No. 2 (2012) 
TABLE 3. Effect of interaction between intercropping crops and patterns on growth yield and yield components of maize (main crop) of the combined data.

\begin{tabular}{|c|c|c|c|c|c|c|c|c|c|c|c|}
\hline \multicolumn{2}{|c|}{ Intercropping } & \multirow[t]{2}{*}{$\begin{array}{c}\text { Plant } \\
\text { height } \\
(\mathrm{cm})\end{array}$} & \multirow[t]{2}{*}{$\begin{array}{c}\text { Ear } \\
\text { height } \\
(\mathbf{c m})\end{array}$} & \multirow[t]{2}{*}{$\begin{array}{c}\text { Ear } \\
\text { length } \\
(\mathbf{c m})\end{array}$} & \multirow[t]{2}{*}{$\begin{array}{c}\text { Ear } \\
\text { diameter } \\
(\mathbf{c m})\end{array}$} & \multirow[t]{2}{*}{$\begin{array}{c}\text { No. of } \\
\text { grain/ } \\
\text { row }\end{array}$} & \multirow{2}{*}{$\begin{array}{l}\text { Wt.of } \\
100 \\
\text { grain } \\
(g)\end{array}$} & \multirow{2}{*}{$\begin{array}{l}\text { Wt.of } \\
\text { grain/ } \\
\text { ear } \\
(\mathrm{g})\end{array}$} & \multirow[t]{2}{*}{$\begin{array}{c}\text { Shelling } \\
\%\end{array}$} & \multirow[t]{2}{*}{$\begin{array}{l}\text { Grain } \\
\text { yield/ } \\
\text { ardab }\end{array}$} & \multirow[t]{2}{*}{$\begin{array}{c}\text { Percentage } \\
\text { of light } \\
\text { intensity }\end{array}$} \\
\hline crops & patterns & & & & & & & & & & \\
\hline \multirow{3}{*}{$\mathrm{A}_{1}$} & $\mathrm{P}_{1}$ & 285.3 & 163.00 & 20.87 & 3.55 & 48.00 & 34.67 & 227.83 & 84.87 & 13.63 & 23.50 \\
\hline & $\mathrm{P}_{2}$ & 278.8 & 163.83 & 22.20 & 3.78 & 51.75 & 37.17 & 229.67 & 85.00 & 8.34 & 25.50 \\
\hline & $\mathrm{P}_{3}$ & 282.0 & 159.50 & 24.27 & 3.55 & 53.08 & 39.00 & 229.92 & 84.55 & 16.28 & 23.67 \\
\hline \multirow{3}{*}{$\mathrm{A}_{2}$} & $\mathrm{P}_{1}$ & 289.7 & 161.50 & 22.35 & 3.77 & 50.83 & 36.50 & 234.67 & 82.20 & 15.47 & 33.90 \\
\hline & $\mathrm{P}_{2}$ & 288.0 & 167.00 & 23.12 & 4.11 & 52.22 & 40.17 & 237.17 & 85.42 & 9.16 & 35.50 \\
\hline & $\mathrm{P}_{3}$ & 282.7 & 158.50 & 22.05 & 3.76 & 51.58 & 38.00 & 237.83 & 84.43 & 17.91 & 32.88 \\
\hline \multirow{3}{*}{$\mathrm{A}_{3}$} & $P_{1}$ & 297.8 & 174.17 & 22.70 & 3.62 & 50.08 & 34.67 & 230.50 & 84.70 & 14.86 & 33.50 \\
\hline & $\mathrm{P}_{2}$ & 290.3 & 171.50 & 24.08 & 4.02 & 52.88 & 39.17 & 234.67 & 85.87 & 9.56 & 35.50 \\
\hline & $\mathrm{P}_{3}$ & 300.8 & 166.33 & 21.49 & 3.81 & 53.42 & 36.33 & 236.83 & 84.67 & 18.31 & 34.50 \\
\hline \multicolumn{2}{|c|}{ LSD $5 \%$} & NS & 7.39 & 1.40 & NS & 1.81 & 1.33 & NS & NS & 0.75 & NS \\
\hline \multicolumn{2}{|c|}{ Solid } & 277.45 & 155.85 & 21.45 & 3.27 & 46.10 & 33.3 & 223.8 & 84.65 & 20.39 & 22.99 \\
\hline
\end{tabular}

$\mathrm{A}_{1}$ (maize + sorghum) $\mathrm{A}_{2}$ (maize + soybean), $\mathrm{A}_{3}$ (maize + cowpea)

$\mathrm{P}_{1}(2: 2), \mathrm{P}_{2}(2: 4), \mathrm{P}_{3}(4: 4)$

Hectare $=10.000 \mathrm{~m}^{2}$, feddan $=4200 \mathrm{~m}^{2}$, maize $\operatorname{ardab}=140 \mathrm{~kg}$

Intercropping effect on intercropped crops

Intercropped crops (sorghum, soybean and cowpea) were significantly affected by intercropping systems (Tables 4, 5 and 6). The yield and yield components of sorghum, soybean and cowpea were decreased as compared with solid. The reduction in yield and yield components may be due to the shading of maize plants, this reduction can be attributed to the shading from top of maize plants to top of intercropped crops (soybean and cowpea), which in turn decreased interception of solar radiation. Data on light intensity within sorghum, soybean and cowpea within plants at 70 days age had lower values for intercepted light intensity as compared with solid planting. The reduction in light intensity at middle of soybean and cowpea plants in maize + soybean and maize + cowpea intercrops were 39 and $38 \%$, but maize + sorghum intercrop was lesser $17 \%$ than within plants of soybean and cowpea in the combined of the two seasons. The grain, seed and straw yield of intercropped crops were lower than solid planting. This reduction in yields may be due to the plants density of intercropped crops which was lower than solid planting and shading by maize canopy. Similar results were observed by Donald (1961). 
The intercropping patterns effects on grain and seed yield of intercropped crops were observed (combined of both seasons). The reduction in yield were 61, 43 and 59\% for sorghum, 60, 33 and $60 \%$ for soybean and 53, 33 and 58\% for seed cowpea in 2:2, 2:4 and 4:4 patterns (combined of the two seasons), respectively. The alternate pattern $2: 4$ had the highest values of intercepted light intensity on intercropped crop plants than the other intercropping patterns $(2: 2$ and 4:4). The advantage of alternating ridge of 2:4 in light penetration over alternated ridge of $2: 2$ and 4:4 patterns may be due to spatial arrangement of this pattern which had the lowest number of maize plants per unit area $(33 \%$ of solid planting) as compared to the other intercropping patterns (50\% of solid planting). The results indicated that intercropping patterns caused significant reduction in light interception through adjacent maize plants, the low availability of light for a component crop growth rate, finally leading to drastic reduction in grain, seeds and straw yield of components crops (Donald, 1961). These results are in the same context of those obtained by Metwally et al. (2009).

TABLE 4. Effect of intercropping patterns on growth yield and yield components of sorghum of the two seasons and combined data.

\begin{tabular}{|c|c|c|c|c|c|c|c|}
\hline $\begin{array}{l}\text { Intercropping } \\
\text { patterns }\end{array}$ & $\begin{array}{c}\text { Plant } \\
\text { height } \\
(\mathrm{cm})\end{array}$ & $\begin{array}{c}\text { Wt. } \\
\text { of } \\
\text { head } \\
(\mathrm{g})\end{array}$ & $\begin{array}{c}\text { Wt.of } \\
100 \\
\text { kernels } \\
\quad(g) \\
\\
\text { Seas }\end{array}$ & $\begin{array}{c}\text { Wt.of } \\
\text { kernel/ } \\
\text { head } \\
(\mathrm{g}) \\
2008\end{array}$ & $\begin{array}{c}\text { Shelling } \\
\%\end{array}$ & $\begin{array}{c}\text { Grain } \\
\text { yield/ardab }\end{array}$ & $\begin{array}{c}\text { Percentage } \\
\text { of light } \\
\text { intensity }\end{array}$ \\
\hline \multicolumn{8}{|c|}{ Season 2008} \\
\hline $2: 2$ & 121.3 & 136.67 & 4.33 & 33.00 & 35.00 & 5.67 & 19.33 \\
\hline $2: 4$ & 123.3 & 141.00 & 4.23 & 33.00 & 39.33 & 8.67 & 21.33 \\
\hline $4: 4$ & 129.7 & 144.00 & 4.87 & 36.67 & 40.67 & 6.33 & 20.33 \\
\hline LSD 5\% & NS & NS & NS & NS & NS & 1.00 & NS \\
\hline Solid & 133.3 & 161.67 & 5.10 & 48.67 & 33.67 & 15.14 & 24.76 \\
\hline \multicolumn{8}{|c|}{ Season 2009} \\
\hline $2: 2$ & 133.3 & 127.00 & 5.10 & 34.00 & 43.67 & 5.45 & 18.67 \\
\hline $2: 4$ & 132.7 & 152.67 & 5.33 & 33.00 & 42.67 & 7.69 & 21.67 \\
\hline $4: 4$ & 126.7 & 151.67 & 5.23 & 37.00 & 41.67 & 5.43 & 20.00 \\
\hline LSD 5\% & NS & 11.41 & NS & 3.42 & NS & 1.06 & NS \\
\hline Solid & 136.7 & 160.00 & 5.27 & 48.00 & 41.00 & 13.57 & 24.00 \\
\hline \multicolumn{8}{|c|}{ Combined of the two seasons } \\
\hline $2: 2$ & 127.3 & 135.50 & 4.72 & 33.67 & 39.33 & 5.56 & 19.00 \\
\hline $2: 4$ & 128.0 & 146.83 & 4.78 & 33.00 & 41.00 & 8.18 & 21.50 \\
\hline $4: 4$ & 128.2 & 144.17 & 5.05 & 36.83 & 41.00 & 5.88 & 20.17 \\
\hline LSD 5\% & NS & 17.30 & NS & 6.18 & NS & 3.19 & NS \\
\hline Solid & 135.0 & 160.83 & 5.18 & 48.33 & 37.33 & 14.36 & 24.38 \\
\hline
\end{tabular}

Hectare $=10.000 \mathrm{~m}^{2}$, feddan $=4200 \mathrm{~m}^{2}$, sorghum ardab $=140 \mathrm{~kg}$

Egypt. J. Agron. 34, No. 2 (2012) 
TABLE 5. Effect of intercropping patterns on growth yield and yield components of soybean of the two seasons and combined data .

\begin{tabular}{|l|c|c|c|c|c|c|c|c|} 
Characters & $\begin{array}{c}\text { Plant } \\
\text { height } \\
\text { (cm) }\end{array}$ & $\begin{array}{c}\text { No.of } \\
\text { branches } \\
\text { Intercopping } \\
\text { patterns }\end{array}$ & $\begin{array}{c}\text { No.of } \\
\text { seed/ } \\
\text { plant }\end{array}$ & $\begin{array}{c}\text { No.of } \\
\text { seed/ } \\
\text { pod }\end{array}$ & $\begin{array}{c}\text { Wt.of } \\
\text { 100 seed } \\
\text { (g) }\end{array}$ & $\begin{array}{c}\text { Seed } \\
\text { yield } \\
\text { (ton) }\end{array}$ & $\begin{array}{c}\text { Straw } \\
\text { yield/ } \\
\text { (ton) }\end{array}$ & $\begin{array}{c}\text { Percentage } \\
\text { of light } \\
\text { intensity }\end{array}$ \\
\hline \multicolumn{7}{|c|}{ Season 2008 } \\
\hline $2: 2$ & 61.0 & 4.97 & 18.33 & 7.67 & 11.83 & 0.369 & 0.250 & 3.19 \\
\hline $2: 4$ & 71.0 & 5.73 & 22.33 & 9.80 & 13.43 & 0.505 & 0.887 & 6.70 \\
\hline $4: 4$ & 60.7 & 5.03 & 16.33 & 7.23 & 9.23 & 0.333 & 0.287 & 6.23 \\
\hline LSD 5\% & 5.21 & 0.49 & 2.25 & 0.71 & 1.15 & 0.072 & 0.026 & 0.30 \\
\hline Solid & 7.5 & 6.3 & 26.33 & 10.50 & 15.00 & 0.823 & 1.547 & 9.23 \\
\hline \multicolumn{7}{|c|}{ Season 2009 } & & \\
\hline $2: 2$ & 61.7 & 4.93 & 20.33 & 7.67 & 10.33 & 0.433 & 0.410 & 4.40 \\
\hline $2: 4$ & 65.3 & 5.77 & 23.67 & 8.77 & 11.67 & 0.637 & 0.860 & 6.80 \\
\hline $4: 4$ & 61.3 & 6.03 & 17.33 & 7.30 & 8.83 & 0.383 & 0.320 & 6.47 \\
\hline LSD 5\% & NS & 0.53 & 3.42 & 0.90 & 1.36 & 0.041 & 0.036 & 0.43 \\
\hline Solid & 75.7 & 6.40 & 26.00 & 11.33 & 16.33 & 0.880 & 1.743 & 9.07 \\
\hline \multicolumn{7}{|c|}{ Combined of the two seasons } \\
\hline 2:2 & 61.4 & 4.95 & 19.33 & 7.67 & 11.08 & 0.401 & 0.330 & 3.80 \\
\hline $2: 4$ & 68.2 & 5.75 & 23.00 & 9.28 & 12.55 & 0.571 & 0.873 & 6.75 \\
\hline $4: 4$ & 61.0 & 5.53 & 16.83 & 7.27 & 9.03 & 0.358 & 0.303 & 6.35 \\
\hline LSD 5\% & 6.36 & 0.141 & 4.32 & 1.23 & 2.39 & 0.089 & 0.045 & 0.54 \\
\hline Solid & 75.7 & 6.35 & 26.17 & 10.92 & 15.67 & 0.852 & 1.645 & 9.15 \\
\hline
\end{tabular}

TABLE 6 . Effect of intercropping patterns on growth yield and yield components of cowpea of the two seasons and combined data .

\begin{tabular}{|c|c|c|c|c|c|c|}
\hline $\begin{array}{l}\text { Characters } \\
\text { Intercropping } \\
\text { patterns }\end{array}$ & $\begin{array}{c}\text { Plant } \\
\text { height } \\
\text { (cm) }\end{array}$ & $\begin{array}{c}\text { No.of } \\
\text { seed/pod }\end{array}$ & $\begin{array}{c}\text { No.of } \\
\text { pod/plant }\end{array}$ & $\begin{array}{l}\text { Seed yield } \\
\text { (ton) }\end{array}$ & $\begin{array}{c}\text { Straw } \\
\text { yield } \\
\text { (ton) }\end{array}$ & $\begin{array}{c}\text { Percentage } \\
\text { of light } \\
\text { intensity }\end{array}$ \\
\hline \multicolumn{7}{|c|}{ Season 2008} \\
\hline $2: 2$ & 83.3 & 2.47 & 25.67 & 0.618 & 0.950 & 3.66 \\
\hline $2: 4$ & 85.0 & 2.53 & 37.67 & 1.033 & 1.600 & 5.43 \\
\hline $4: 4$ & 86.0 & 2.40 & 32.67 & 0.600 & 1.300 & 5.97 \\
\hline LSD 5\% & NS & NS & 1.31 & 0.072 & 0.184 & 0.55 \\
\hline Solid & 96.7 & 2.53 & 59.03 & 1.496 & 2.880 & 8.40 \\
\hline \multicolumn{7}{|c|}{ Season 2009} \\
\hline $2: 2$ & 86.3 & 2.53 & 33.00 & 0.552 & 1.100 & 3.85 \\
\hline $2: 4$ & 89.7 & 2.53 & 37.33 & 0.927 & 1.500 & 5.97 \\
\hline $4: 4$ & 88.3 & 2.57 & 36.33 & 0.567 & 1.200 & 6.33 \\
\hline LSD 5\% & NS & NS & NS & 0.051 & 0.181 & 0.69 \\
\hline Solid & 101.3 & 2.47 & 63.00 & 1.430 & 2.95 & 8.80 \\
\hline \multicolumn{7}{|c|}{ Combined of the two seasons } \\
\hline $2: 2$ & 84.8 & 2.50 & 29.33 & 0.585 & 1.025 & 3.76 \\
\hline $2: 4$ & 87.3 & 2.53 & 37.50 & 0.980 & 1.550 & 5.70 \\
\hline 4:4 & 87.2 & 2.48 & 34.50 & 0.583 & 1.250 & 6.15 \\
\hline LSD 5\% & 14.19 & NS & 13.37 & 0.210 & 0.368 & 1.10 \\
\hline Solid & 99.0 & 2.50 & 61.0 & 1.463 & 2.915 & 8.60 \\
\hline
\end{tabular}




\section{Competitive relationships and yield advantages}

Data in Table 7 indicates that land equivalent ratio (LER), Relative crowding coefficient $(\mathrm{K})$, Aggressivity $(\mathrm{Ag})$ competitive ratio (CR) and monetary advantage index (MAI) varied considerably due to the effect of competition in the intercropping patterns in the combined data of the two seasons.

The results reveal that the $\mathrm{Ry}_{\mathrm{m}}$ values of the main crop (maize) were affected by intercropped crops. The highest mean value $(0.70)$ was observed in both maize + soybean and maize + cowpea intercrops, The $\mathrm{Ry}_{\mathrm{m}}$ in maize + sorghum intercrop were higher (0.62), but lesser than in maize+ legume intercrops which indicate that there was an advantage for maize when intercropping with legume crops, while the Ry, of intercropped crops were more decreased (0.46-0.52).

Also, the $R y_{m}$ values of maize were affected by intercropping patterns. The 4:4 pattern had higher mean over all values of $\mathrm{Ry}_{\mathrm{m}}(0.77)$ and $2: 4$ pattern had lowest values (0.43), which indicate that the $4: 4$ pattern was more advantageous for maize, while the Ry of intercropped crops were over $(0.62)$ in $2: 4$ pattern and low (0.43) in the other patterns.

The total LER, values were greater than one when intercropping with means soybean and cowpea intercrop (1.19 and 1.22). This indicates that 19 and 22\% more area would be required by sole cropping system to equal the yield of intercropping system (Dhima et al., 2007).

A similar trend to that of LER was also observed for RCC, Aggressivity and competitive ratio. The RCC (K) values of maize were greater than values $\mathrm{K}$ of the intercropped crops, which indicated, that maize crop is more competitive than its associated crops. The highest mean $\mathrm{K}$ value of maize (4.05 and 4.49) were observed when intercropped with soybean and cowpea, respectively, which indicate that maize crop in maize +legume crops had higher competition than in maize + sorghum (Dhima et al., 2007). The total mean $\mathrm{K}$ was greater in maize+legume crops (3.16 and 3.95) than in maize+sorghum (1.63), which indicates a definite yield advantage due to intercropping with legume crops as compared with cereal crops.

The data of aggressivity showed that main crops (maize) were the dominant ( $A_{m}$ positive) and the values of intercropped crops were dominate (A negative) in all cases. The values were greater mean with legume crops $(+0.68$ and -0.63$)$ than with sorghum (0.56). Similar results were observed by Dhima et al. (2007)

The $\mathrm{CR}$ values of maize were greater than the $\mathrm{CR}$ of intercropped crops. The highest values of $\mathrm{CR}_{\mathrm{m}}$ (2.2) was observed with maize+ soybean intercrop in 4:4 pattern intercrop and the lowest values (1.32) was observed with maize + cowpea intercrop in 4:4 pattern. This indicated that the maize crops was dominant crop and more competitive than intercropped crops (Dhima et al., 2007). 
EFFECTS OF INTRA-INTERSPESIFIC COMPETITIONS ...

\begin{tabular}{|c|c|c|c|c|c|c|c|c|}
\hline \multicolumn{2}{|r|}{$\sum$} & 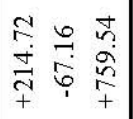 & \begin{tabular}{r|}
$\overrightarrow{1}$ \\
$\overrightarrow{8}$ \\
+ \\
+
\end{tabular} & 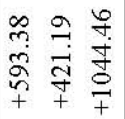 & \begin{tabular}{|l|}
\multirow{2}{*}{} \\
. \\
0 \\
0 \\
0 \\
+ \\
+
\end{tabular} & 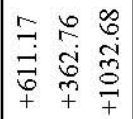 & $\begin{array}{l}\vec{\infty} \\
\ddot{0} \\
0 \\
+ \\
+\end{array}$ & 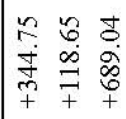 \\
\hline \multirow{2}{*}{ f } & $\stackrel{n}{0}$ & \begin{tabular}{lll}
$\infty$ & $\vec{n}$ \\
\hdashline & $\stackrel{0}{0}$ & 0 \\
0 & 0 & 0
\end{tabular} & $\begin{array}{l}8 \\
0 \\
0\end{array}$ & 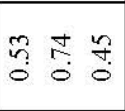 & $\begin{array}{l}n \\
0 \\
0\end{array}$ & $\begin{array}{ccc}0 \\
0\end{array}$ & $\overrightarrow{0}$ & 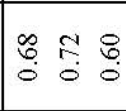 \\
\hline & 竎 & 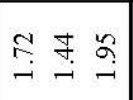 & $\stackrel{?}{-1}$ & 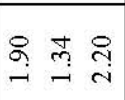 & $\overrightarrow{-\infty}$ & 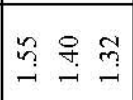 & f & $\stackrel{n}{n} \underset{-}{-} \underset{-}{-}$ \\
\hline \multicolumn{2}{|r|}{ 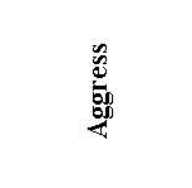 } & 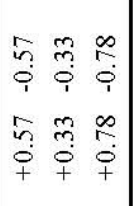 & $\begin{array}{l}0 \\
n \\
i \\
0 \\
\mathscr{2} \\
o \\
+ \\
+\end{array}$ & 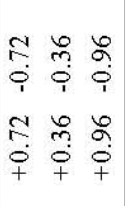 & \begin{tabular}{|c|}
$\infty$ \\
0 \\
0 \\
$i$ \\
$\infty$ \\
0 \\
0 \\
+ \\
+
\end{tabular} & 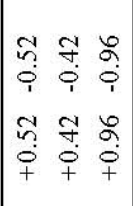 & $\begin{array}{l}0 \\
0 \\
i \\
0 \\
0 \\
\dot{+} \\
+\end{array}$ & 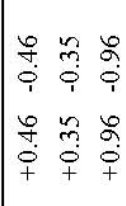 \\
\hline \multicolumn{2}{|r|}{ 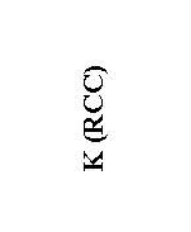 } & 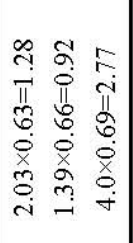 & 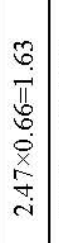 & 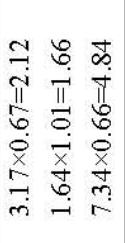 & $\mid \begin{array}{c}0 \\
0 \\
\tilde{\pi} \\
\infty \\
0 \\
\dot{0} \\
\dot{x} \\
0 \\
0 \\
\dot{\sigma}\end{array}$ & 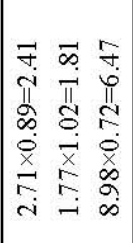 & 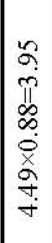 & 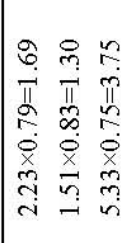 \\
\hline \multicolumn{2}{|r|}{ 鲎 } & 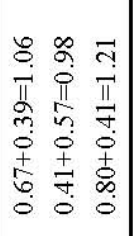 & $\mid \begin{array}{l}0 \\
0 \\
0 \\
\bar{b} \\
\vdots \\
0 \\
\vdots \\
0 \\
0 \\
0\end{array}$ & 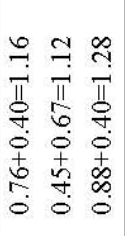 & 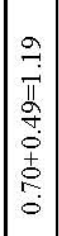 & 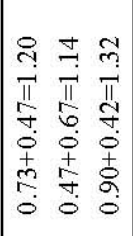 & 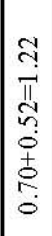 & 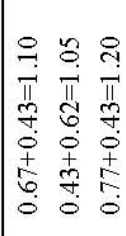 \\
\hline \multicolumn{2}{|r|}{ 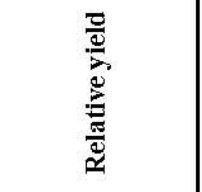 } & 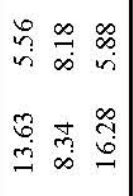 & \multirow{3}{*}{ 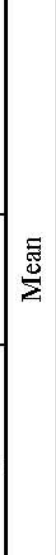 } & 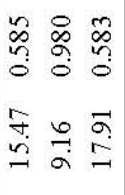 & \multirow{3}{*}{ 丞 } & 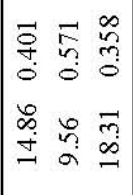 & \multirow{3}{*}{ 丞 } & 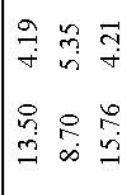 \\
\hline & 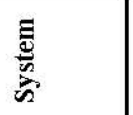 & 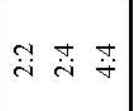 & & $\stackrel{\sim}{i} \underset{i}{\dot{\sim}}$ & & $\stackrel{\sim}{\dot{i}} \underset{\dot{i}}{*}$ & & $\stackrel{\sim}{i} \underset{i}{\dot{i}}$ \\
\hline $\begin{array}{l}\text { on } \\
\frac{20}{2} \\
\frac{2}{0}\end{array}$ & 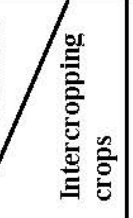 & 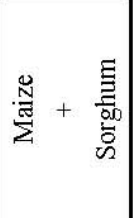 & & 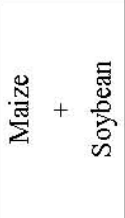 & & 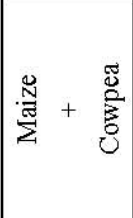 & & 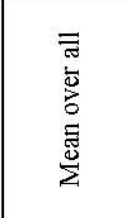 \\
\hline
\end{tabular}

Egypt. J. Agron. 34, No. 2 (2012) 
Monetary advantage index (MAI)

The MAI values were positive in all cases except in maize + sorghum intercrop with 2:4 pattern were negative. These positive MAI values were observed in the other intercropping systems which had LER and $\mathrm{K}$ values greater than one, while the negative MAI values were where LER and $\mathrm{K}$ were lesser than one.

The highest MAI value $(+1044.46)$ was observed in maize + soybean followed by maize+ cowpea intercrops $(+1032.68)$ with $4: 4$ patterns, while the lowest value (-67.16) was observed with maize+ sorghum intercrop in 2:4 pattern.

Similarly, Dhima (2007) and Abou-Keriasha et al. (2009) found that economic benefit expressed with higher MAI values in intercropping.

\section{Conclusion}

The results indicate that maize grain yield in the combination maize+ soybean or maize+ cowpea intercrops were higher than maize + sorghum intercrop. Highest availability of light in the intercrop maize+ soybean or maize + cowpea increased the photosynthesis rate and crop growth rate, so limited lighting leads to drastic increasing in grain yield of crops. The availability of light interception in $2: 4$ patterns was greater than in other patterns $(2: 2,4: 4)$ which help to increase the yield components of maize in 2:4 pattern compared to other patterns. The highest values of LER, RCC, CR and MAI were calculated for maize+ soybean and maize+ cowpea intercrops which were higher than maize + sorghum intercrop.

\section{References}

Abo-Hegazy, Dina R. (2010) Growing corn and soybean under three intercropping patterns. M.Sc. Thesis, Fac. Agric., Cairo Univ., Egypt, 106 p.

Abou-Keriasha, M.A., El-Habbak, K.E. and Shams, S.A.A. (1993) Effect of intercropping soybean with some sorghum varieties on yield and yield components of the intercrops. Egypt. J. Apple. Sci. 18 (6), 873-881.

Abou-Keriasha, M.A., Haikel, M.A. and Farghly, B.S. (1996) Performance of some short and long statured sorghum and sunflower varieties under solid and intercropped planting. J. Agric. Sci . Mansoura Univ. 21 (4),1219-1228.

Abou-Keriasha, M.A., Abd El-Hady, M.A. and Nawar, F.R. (2009) Response of some cowpea varieties to intercropping in maize fields under upper Egypt conditions. Egypt.J. Appl. Sci. 24 (2B), 495-514.

Agyare, W.A., Clottey, V.A., Mercer-Quarshie, H. and Kombiok., J.M. (2006) Maize yield Response in a Long-term rotation and intercropping systems in the Guinea Savannah Zone of Northern Ghara. Journal of Agronomy, 5 (2), 232-238.

Egypt. J. Agron. 34, No. 2 (2012) 
Alexander, Taylor R., Will Burnett, R. and Zim, H. (1970) "Botany". New York: Golden Press, Western Publishing Company.

Behairy, T.G. (1994) Effect of intercropping patterns on soybean growth and photosynthesis apparatus Egyptian Journal of Physiological Sciences, 18, 167-178.

Caballero, R., Goicoecchea, E.L. and Hernaiz, P.J. (1995) Forage yields and quality of common vetch and oat sown at varying seeding ratios and seeding rates of common vetch. Field Crops Res. 41, 135-140.

Chandel, A.S., Singh, V.K. and Saxena, S.C. (1993) Canopy characters net assimilation rate competitive indices and grain yield of soybean (Glycine max) intercropped with maize (Zea mays) in north India. Indian Journal of Agricultural Sciences, 63, 220-224.

Dewit, C.T. (1960) On competition, verslag land bovwkundige Onder Zoek No.66 (8),1-82.

Dhima, K.V., Lithourgidis, A.S., Vasilakoglou, I.B. and Ordas, C.A.D (2007) Competition indices of common vetch and cereal intercrops in two seeding ratio. Field Crops Res. 100, 249-256.

Donald, C.M. (1961) Competition for light in crops and pastures. Symposium Experiment Biology, 15, pp. 282-313.

Echezona, B.C. (2007) Corn-stalk lodging and borer damage as influenced by varying corn densities and planting geometry with soybean (Glycine max. L. Merrill) International Agrophysics. Institute of Agrophysics, Polish Academy of Sci., Lublin, Poland, 21 (2)pp. 133 - 143.

Elmure, R.W. and Jockoba, J.A. (1984) Yield and yield components of sorghum and soybean of varying plant heights when intercropped. Agron. J. 176, 561-564.

Fortin, M.C., Culley, J. and Edwards, M. (1994) Soil water, plant grant growth, and yield of strip intercropped corn. J.Prod. Agric. 7, 63-69.

Lesoing,G.W. and Francis, C.A. (1999) Strip intercropping effects on yield and yield components of corn, grain sorghum and soybean. Agron. J. 91, $807-813$.

Mc-Gilichrist, C.A. (1960) Analysis and competition experiments. Biometrics, 21, 975-985.

Metwally, A.A., Shafik, M.M., EL-Habbak, K.E. and Abdel-Wahab, Sh.I. (2009) Step forward for increasing intercropped soybean yield with maize. The $4^{\text {th }}$ Conf., Recent Technologies in Agric., 3-5 Nov., Cairo Univ., 2: pp. 256 - 269.

Metwally, A.A., Shafik, M.M., Sherief, M.N. and Abdel-Wahab, T.I. (2010) Effect of intercropping corn on Egyptian cotton characters. J. Cotton Sci., U.S.A. (In press).

MSTATC (1980) A Microcomputer Program of the Design Management and Analysis of Agronomic Research Experiments. Michigan State Univ., USA. 
Sanari Moriri, L.G.Owoeye and Mariga, I.K. (2010) Influence of component crop densities and planting patterns on maize production in dry land maize/ cowpea intercropping systems. African J. Agric. Res. 5 (11) 1200-1207.

Songa, J.M., Jiang, N., Schulthess, F. and Omwega (2007) The role of intercropping different cereal species in controlling lepidopteron stenborers on maize in Kenya, J.Appl. Entomol. 131(1), 40-49.

Snedecor,G.W. and Cochran, W.G. (1988) "Statistical Methods". $7^{\text {th }}$ ed.Iowa State Univ. Press, Ames, Iowa, USA.

Szeicz, J., Monteith, L. and Dos Santos, J.M. (1964) Tube solarimeter to measure radiation among plants. J.Appl. Ecol. 1, 169-174.

Tranbath, B.R. (1974) Blomass productivity of mixtures. Adv. Agron. 26, 177-210.

Vandermeer, J.H. (1989) "The ecology of Intercropping Systems". Cambridge University Press, New York.

Willey, R.W. and Osiru, S.O. (1972) Studies on mixture of maize and beans (Phasolus vulgaris) with particular reference to plant populations. J.Agric. Sci. Camb. 79, 519529.

Willey, R.W. (1979) Intercropping its importance and research needs. part 1: Competition and yield advantages. Field Crops Abst. 32, 1 -10.

Willey, R.W. and Rao, M.R. (1980) Competitive ratio for quantifying competition between intercrops. Exp. Agric. 16, 117-125.

(Received 21/11/2012; accepted 4 / 2 / 2013) 


\section{تأثثير التنافس البينى والنوعى على المحصول ومكوناته للأرة الثامية تحت نظم تحميل مختلفة الثين عانئ}

محمد أبو العيون أبو كريثة ، رأفت عايد جاد الله و نبيه محمد حسن الوكيل

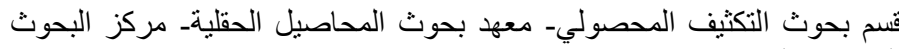

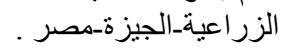

أقيمت تجربتان خلال موسمى الزراعة الصيفى 2008-2009 فى محطة بحوث

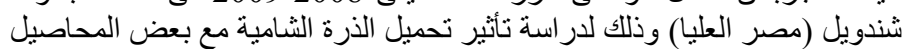
المختلفة ( ذرة رفيعة + فول الصويا + لوبيا العلف) وأثره على على المحصول

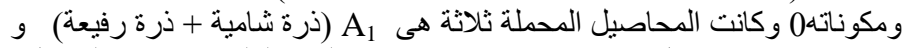

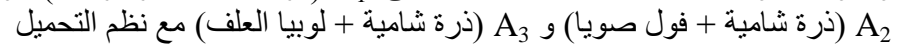
 الستخدم فى التجربة قطع منشقة مرة واحدة فى قطاعات كاملة العشو ائية .

وتثير النتائج إلى أن أعلى قيم لصفات مكونات الدحصول في الذرة الثنامية

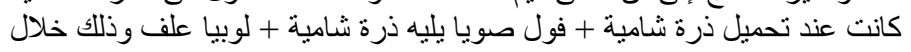

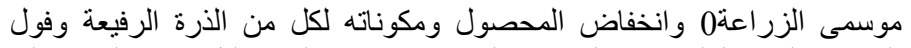

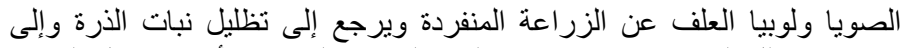

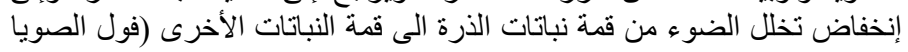
ولوبيا العلف)

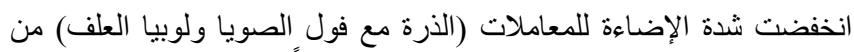

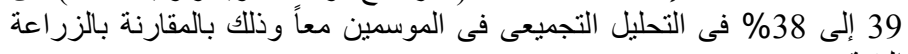
النقية 0

أثرت نظم التحميل على الحصصول ومكوناته للمحاصيل المحملة وسجلت أعلى ألى

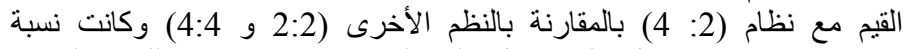

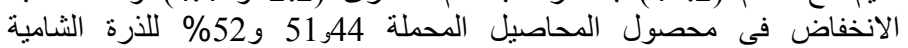

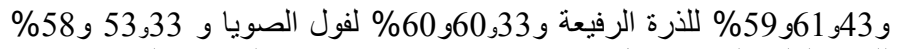
للوبيا العلف لنظم تحميل 2:2 و 2: 4 و 4 4:4 مقارنة بالزراعة الفردية فى كلا الموسمين على التو الى الميل

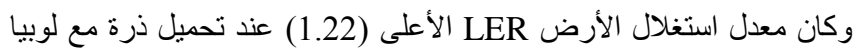

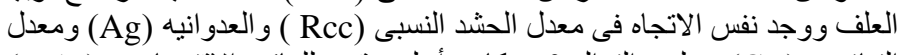

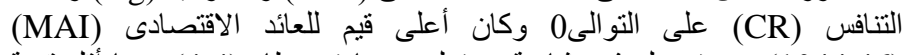

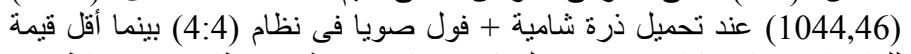

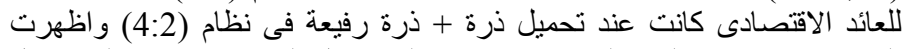

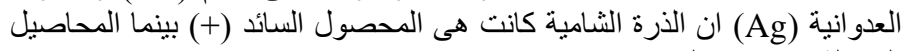

المحملة كانت هى المسوده (-) النيان 